\title{
A SKETCH OF THE EVOLUTION OF ALLODIAL TITLES IN HAWAII.
}

The feudal system of land tenure in England had a curious duplicate in the system evolved by the Polynesian race, on the Hawaiian Islands, probably the most remote spot on the seas, excepting the much-sought Arctic poles.

This civilization came to the Hawaiian Islands from the south twenty-one generations before the present century. Tradition tells of frequent voyages in double canoes from the Samoan Islands, and the bringing of pigs and chickens on these long voyages to the islands, where they were about the only vertebrates found by Captain Cook. There is no tradition, however, of any of these adventurous colonizers bringing with them Coke on Littleton, Blackstone, nor any learned work on the feudal land tenure. It is not generally believed that Kamehameha I. (who flourished as a contemporary of Napoleon, whose miniature counterpart he was) had ever been a great student of Blackstone; oh, happy man! We are not informed that he ever heard of William the Conqueror, or of the battle of Hastings, or of the Domesday Book.

Therefore, we can claim that the great warrior, or his predecessors, built up their system of land tenure, without consulting the eminent authorities, and what similarity there is between the Hawaiian and the feudal system is the result of applying the most ready solution to the same problem.

Hawaiian history does not show that Kamehameha I., pored over the account of William's landing on the English coast, and defeating the flower of English chivalry there, and then closing the book, rolled up his feather cloak, ordered his canoes and started for Honolulu, Oahu, to repeat the performance, and drive the last remnant of resisting local chiefs up the narrowing Nuuanu valley, back of Honolulu, and over the precipice, the famous pali. But he could not have better imitated his prototype if he had.

Like William, Kamehameha I., was a man of commanding person, political sagacity and generous to his friends; like Napoleon, he fought his way from comparative obscurity. Kameha- 
meha portioned out the various islands to his chiefs in return for a certain portion of the fruits of the soil, which they were to give him. The greater chiefs, in turn, divided their great tracts to their favorites, retaining a portion of the produce as rent.

The land so passed through four, five or six hands, until the wretched common kanaka found, himself the actual tiller of the soil, that he was allowed to live on. only during the will of his superior lord. From the produce of this labor he was allowed to retain only enough sustenance to keep himself alive to work another day for his superior lord.

There was no stability in the system. The tenancy lasted at the will of either party. Unlike the serfs, the kanaka might emigrate whenever he chose. No ties of fealty, nothing that resembled the banding together of warriors for defense and selecting a chief is found in their customs. It was rather a thor. ough, and consistent carrying out of the spoils system from top to bottom of the Hawaiian despotism, a machinery built up and operated by the chiefs with the aid of their kahunas, or priests. The government in Hawaii was more highly organized than any other in Polynesia, and consequently the chiefs were more powerful. When the king died there was an entirely new distribution of lands, down to the poorest native, on whom the burden of all expense ultimately fell ("The Polynesian Race." by Fornander, Vol. II., p. 300). The native had no right to the small kuleana or patch of taro land on which he labored up to his waist in mud and water, and built his grass hut, but might be dispossessed at any moment on refusing to continue any of the many menial tasks he was required to perform on his chief's land on stated days of each moon, or for the king on his lands.

This same relation existed between the lesser chiefs and the greater, and between them up to the king. In short, it was a government by "pull" with the conqueror, or. "boss." The same motive of selfishness ruled them among the bronze halfcivilized barbarians, that now gives motive power to the highlyorganized machine that governs the centers of civilization in America.

The title to all lands rested in the king personally; there was no distinction between the private property of the king and that which he held as the representative of the state, a distinction not recognized till $\mathrm{r} 84 \mathrm{O}$. He, only, held the allodium in all lands of Hawaii. His consent was necessary for any transfers of real estate, or for real mortgages also. All lands forfeited for nonpayment of taxes reverted to him (Old Laws, p. r79). He was 
the source of all title, as he is now, if we trace back title suffciently, as will be shown hereafter.

The kings of Hawaii were the only men who knew the law, for the law depended on their arbitrary decrees constrained only by what they feared to do. The only notion the Hawaiian had of law, other than the capricious will of the chiefs and king, were certain customs in regard to water-rights, attached to the lands, wherefore, it is reasonable to understand why the Hawaiian word for law is Kana-zwai, pertaining to water.

The method of dividing the lands among the chiefs was strangely similar to that of William the Conqueror, and the method of dividing the lands a peculiar system, adapted to the physical features of the islands. The five greater islands are especially volcanic in their structure. Maui, for instance, seems to be made up of two great volcanoes joined together by a low isthmus. In the center of these two parts are craters, one the famous Haleakala. The lands are divided with regard to the surface of these great mountains.

The greatest division is a moku, or district dividing some islands into six parts, each comprising many ahupuaa. The ahupuaa may be described as a slice out of the side of the mountain, as if one cut each great volcanic mountain on each island into slices of cake, varying greatly in width. Suppose that the cake have placed in the center of it an elaborate candy design with a point in the middle of the coveted center that occupies, perhaps, one-eighth of the diameter; then suppose that the distributor of the cake, representing the conqueror, give to certain two or three favorites very wide slices and divide the candy center among the three favored ones. Now suppose that the fruit and frosting around the margin of the cake be also divided among these favored ones, and the less favored are content with their small slices, cut off at the center, and without the coveted frosting on the circumference.

These slices are called ahupuaas and constitute the greatest unit of division of land. The ordinary ahupuaa runs from the sea up the side of the volcanic mountain into the timber limit, and into the jungle a mile or two, and there it is cut off by the greater ahupuaas which likewise extend from the sea to the mountain forests, and there broaden out beyond the regular lines cutting off the smaller ahupuaas from the summit of the mountain and dividing the whole of the central forest, fringing the mountain, among the few, the center of the cake is theirs. The right to these forests is indicated by the grant from the 
king of the exclusive right to cut aho and collect cordage, or to take the $o 0$, a bird much prized for two or three yellow feathers its bears, valued for making the feather cloak, a sign of rank; another aluupuca might have the exclusive right so take sandal wood within certain limits of the forest. The lines of these great aluzpulaas come together at the top of the mountain, often at some well-marked point, or crag on the edge of a crater like the Palaha on the crater of Haleakala, East Maui, where eight great ahupuaas from as many districts converge (W. D. Alexander's article in "Thrum's Annual," I89x, p. I05). The small ahupuaas suffer the same curtailment, makai (toward the sea). The great slices of land have attached to them ocean fishing rights, not only on their own shores but spreading out on each side up and down the rocky coasts for miles, till they join another monopoly of the deep-sea fisheries. They possess the exclusive right to fish in the ocean for a mile out to sea from the depth where a man can wade. The small slices carry only the right to fish where a man can wade up to about five feet. Some of the ahupuaas are granted by metes and bounds one mile and a half out to sea. These slices of land, it will be noticed, embrace all kinds of land dear to the kanaka heart-fisheries, their principal flesh food, low land, well watered. which the kanaka works into tiers of square ponds, draining one into the other, where he grows his tara, a water plant of great bulbous root, weighing two or three pounds. He boils these and crushes into a paste with water, and allows it to ferment, until it becomes of the consistency of kite paste, as the boys would call it, and of a slate or pink color. With the fish and poi, a native wants little else, except a few yams, bananas or mangoes grown on the dry or Kula mountain land above, and a right to cut wood in the bit of forest on the upper part of the aluupuaa for fuel, and to obtain bark for kapa, native cloth.

So much for the comfort of the baron or lord of the aluupuaa, his friends and family servants, but the laborers on his lands are to be provided for. In some cases narrow steps of shore and mountain land were rented to the greater suborainates, but this was not always practicable and the common kanaka must be provided with taro and kula lands for his wants. This was accomplished by allowing a kanaka to have a little patch of an acre or two in the rich taro land, and a share in the precious water running by, so that on seven or eight or more days of each moon he might flood his taro patch. Such land, near Honolulu, now sells sometimes for over one thousand dollars an acre. The 
kanaka knew his land not by metes and bounds, but by a particular name, such as Popoke (poor pussy), Honoku (turtle back), and other names some of which would hardly bear translation for their obscenity. It was necessary to provide dry lands for the same native, which could not be done without jumping from the lowlands several miles into the mountains. Another patch usually larger than the precious taro land, will be found by the same name up among the dry lands, where a stone wall may inclose some yams and bananas. J'his patch is called a lele, or jump, of the same Popoke patch below, both pieces are sometimes conveyed by the name merely, often without indicating that there is more than one piece.

Within many ahupuaas were also larger divisions of land, located anywhere within its boundaries, called ili aina (skin, or hide-land). What similarity there may be to Vergil's story about the widow, Dido, and the measuring of Carthage as an ili or tergum of land, I leave to archæologists. 'These ili aincrs were spotted, like the measles, with small kuleanas, or claims of the common kanaka, as mentioned above. The ordinary ili was merely a division of the aluupuaa for the convenience of the chief of that greater division, with an agent, or konoliki, to manage it, who brought the revenue to the chief.

Another kind of ili was the ili kupono (skin standing right), or independent ili, which was independent of the chief of the alıupuaa and held directly from the king, and paying tribute directly to him.

The ilis sometimes scattered over nearly the whole aluupuaa, as one might carelessly throw chips on a pail of water and finc nearly the whole surface covered. Thus the ilis of Waikoloa and Puukapu (forbiclden hill) occupy nine-tenths of the area of the ahupuaa of Waimea. The grant of the aluupuaa would carry ali the lands within its radial lines, excepting ili-kuponos, or independent ilis, whatever area that might have.

Such was the condition of the land system when the American missionaries landed in $1 \delta 20$, and inaugurated an era of progress, in worldly, as well as spiritual affairs. In 1839 , 1840 , Kamehameha III. was induced to issue an edict that the kuleana men or common kanakas should not be deprived arbitrarily of the lands they cultivated, but this proved inadequate. The vicious system continued.

As civilization advanced Kamehameha III., on the advice and instruction of his disinterested and wise counsellors, saw the objections to the system of land tenure, by which all title to land 
was in him, subject to taxes and revenue for himself as well as for the expenses of government, all of which went into the same pocket, if he had one. The need of some record of the lands of his kingdom, and of its subdivisions, was pointed out to him; as also, a record of the occupiers of these lands (Estate of $H$ is Majesty Kamehameha IV., 2 Hawaiian Reports ; 5 ; W. D. Alexander in "Thrum's Annual" cited above).

Accordingly, in 1846 a commission was established by Kamehameha III. to quiet the land titles of the islands. This board of five commissioners was established for the investigation and final ascertainment, or rejection, of all claims of private individuals to any landed property acquired prior to the act, I846 (I Statutes of Hawaii, p. 107). All claims were forever barred unless presented to this board by February 14,1848 , and the land of the ahupuaa reverted to the government, or of the kuleana in the ahupuaa, or ili, to the holder of that body of land. The award of the commission was final unless appealed from. Its existence was limited, and it proceeded with great industry to the enormous task before it of settling the $x 2,000$ land claims on the eight islands, which it completed in 1855 .

It established an elaborate set of principles in its adjudication of claims presented to it. The nature of Hawaiian ten. ure of land and the history of its development, which I have merely outlined, is accurately stated in Statutes of Hawaii, Vol. II., p. $8 \mathrm{x}, \mathrm{x} 846$.

The holders of the ahupuaas and ilis were very anxious to free their lands from all other claims, and willingly gave up one-third of their lands in return for an allodial title to the remainder, thus indicating the good sense of the aristocracy.

Of course it was impossible for the holders of the ahupuaas and ilis to determine the area of their lands until the scattered kuleanas within them were determined. This was necessarily done hastily, and few competent surveyors were to be had. C. $\mathrm{J}$. Lyons, in his articles in the Islander of 1875 , gives an interesting narrative of the methods employed from personal knowledge as an expert surveyor. The distances were sometimes measured by fifty-feet chains and the direction established by a pocket compass, or in one case, in Land Commission's Award 17 , Royal Patent I 30 to E. Jones in Honolulu, the bounds were read off from a mariner's compass. Any natural feature, however ephemeral, was noted-as guava trees, as frail as willow trees in New England. The description might be as follows: Beginning at a guava tree on the N. F. corner of this land and 
running $N$. W. half W. per mariner's compass I chain $55 \mathrm{ft}$. to the S. corner of the pen of the missionary cow, near Kawaiaha; thence along back of same N. E. about I chain 3 feet to a hala tree marked $X$; thence $S$. E. by $E$. one-fourth $E$. about 92 feet, etc.

The direction, whether magnetic or true meridian, is often omitted, and the local variation which is great near great lava flows, is seldom noted. Several methods are sometimes noted in one survey. The same surveyor did not take a whole district, but each worked out his own plans independently of all other surveys, as at Waikiki, where the overlapping and failure to join is a fruitful source of litigation to-day.

With this inaccuracy the difficulty of the owners of ahupuaas may be imagined. The problem that faced them was like answering the question, What is the area of the white on the ten-spot-of-spades without knowing the area of the spades? Add to this the fact that a smaller eight-of-clubs might be placed on top of the larger card, and the problem of the holder of the $i l i$ inside the ahupuaa may be imagined.

The result was that the land commission was empowered to grant titles to konohikis, or agents of chiefs, for whole "ahupuaas or ilis received by them in Mahele of 1848 by their proper mames without survey." These names were such as Kealakekua (the paths of the gods); Kauliako (the bowels that were dragged).

This leads us to a most remarkable peaceful revolution in the land tenure of Hawaii by which the embarrassment of land titles was relieved and all titles became allodial.

The award of the L. C. A., as it is called for short, gave the holder a right to pay one-third of the value of the land, as a commutation of the government interest in the tenant's land. The chiefs still held their larger claims from the lring, and were anxious to secure an allodial title. After a historic debate of the king and chiefs in Privy Council in December, 1847 , the chiefs decide to surrender to the king the greater part of the lands held in fief by them, in return for an allodium in the remainder, but that was accomplished by two steps. The first step was the great makele, or division by which a committee arranged by mutual consent of the king and each chief, a settlement that was to be final. The landlords were to receive one-third of the lands held by them, as their share. The record of this division was kept in the Mahele Book, the Hawaiian Domesday Book, which consists of lists of lands by name belonging to the king, and chiefs to which mutual quitclaim deeds are 
subjoined by which the king released all his feudal rights in the chiefs' lands (see the learned opinion of Hon. A. F. Judd, now Chief-Justice (Yale '62), in Harris $v$. Carter, $6 \mathrm{Haw}$. 198). The allodium was not even then in either the king or the chiefs.

The chiefs were required to present their claims to the Land Commission for award, upon which they might secure an allodial title to their lands in a Royal Patent, upon paying a commutation to the Government for its interest in the lands (Kanoa $v$. Meek, $6 \mathrm{H} .63)$. At the close of the mahele, or division, the lands of the king reserved to himself to which the landlords or chiefs had quitclaim, were not regarded by him as his private property. "Even before his division with the landlords, a second division between himself and the government or state was clearly contemplated" (Estate of His Majesty Kamehameha IV., 2 Haw. 722). The king seems to have realized the value of separating his private property from that property held by him as the representative of the state, and to have appreciated the danger of confiscation of public lands, including his own, in case of conquest by a foreign power. He also appreciated the value of complete control over his own property. Impelied by these motives, and apparently by a broad view of the interests of his kingdom, in 1848 he set apart for the use of the government the larger part of his royal domain, afterwards known as government land, and reserved to himself a reasonable amount, as his own estate, known since as crown lands. These deeds are both contained in the Domesday Book of Hawaii, called the Mahele Book, or Book of Division.

In $185^{\circ}$ the chiefs followed the example of their king, and gave up a third of their lands to the government which was accepted by the Privy Council August 26, 1850, as full computation of the Government right in the remainder of their lands; thus the chiefs obtain an allodial title.

The grants of the ahupuaas and ili expressly reserve the rights of tenants, "koe na kuleana o kanaka." In 1862, a boundary commission settled the limits of those aluzpuaas and ilis, awarded by name.

The common people were guaranteed the right to water and the right of way over the lands of their chiefs, or konolikis. The same act of August 6, 1850 , confirms the resolution of the Privy Council on December 2I, I849, granting a fee simple title, free of all commutation to all native tenants for their cultivated lands and house lots, except town lots in Honolulu, Lahaina and Hilo. (W. D. Alexander in "Thrum's Annual," x891, P. II5). 
Thus three classes of the kingdom obtain allodial titles, since which time the government has been industriously locating and mapping the lands of Hawaii, and bringing order out of chaos under the able supervision of W. D. Alexander, Yale '55, Surveyor General. The government maps of ahupuaas, locating kuleanas look like crazy quilts, but still the greater lands are now approximately correct in their calculation of areas.

Now and again, a blind or deaf old kamaaina (oldest inhabitant) is hunted out of his grass hut or cabin, and placed on the witness stand to locate a doubtful kuleana. He is urged to tell the court where the pig pen used to be, or the guava tree, since succeeded by a jungle of others; where the missionary cow had her pen, or the ever-changing bank of the stream its ancient line. In the desire to please, he may answer, "It was just where you would like to have it, judge," and the court does the best it can to locate that particular spot on the ten-of-spades, and the occupants of others sigh for the twenty years of adverse possession to settle their pilikia.

HoNolvL, H. I. 